\title{
PEMODELAN ANGKA HARAPAN HIDUP DAN ANGKA KEMATIAN BAYI DI KALIMANTAN DENGAN REGRESI NONPARAMETRIK SPLINE BIRESPON
}

\author{
Modeling Life Expectations and Infant Death Rates in Kalimantan with \\ Nonparametric Regression Spline Birespon \\ Aprianti Boma Padatuan ${ }^{1}$, Sifriyani $^{2 *}$, Surya Prangga ${ }^{3}$ \\ 1,2,3 Program Studi Statistika, Jurusan Matematika, FMIPA Universitas Mulawarman \\ Jln. Barong Tongkok No.04 Gn. Kelua, Samarinda 75123, Kalimantan Timur, Indonesia
}

Corresponding author e-mail: 12* sifri.stat.unmul@gmail.com

\begin{abstract}
Abstrak
Penelitian ini menggunakan model regresi nonparametrik birespon dengan pendekatan spline truncated. Model tersebut digunakan untuk menyelesaikan permasalahan analisis regresi yang bentuk kurvanya tidak diketahui. Pendekatan spline truncated memiliki fungsi polinomial tersegmen yang memberikan sifat fleksibilitas. Data yang digunakan dalam penelitian ini terdiri dari dua variabel respon yaitu Angka Harapan Hidup (AHH) dan Angka Kematian Bayi (AKB) di Pulau Kalimantan. Tujuan penelitian adalah untuk menentukan model regresi nonparametrik spline truncated birespon pada data AHH dan AKB dan mengetahui faktor-faktor yang mempengaruhi AHH dan AKB. Hasil penelitian diperoleh model terbaik yaitu model regresi nonparametrik spline linier birespon dengan nilai $R^{2}$ sebesar 80,51 persen dan model spline tiga titik knot dengan nilai Generalized Cross Validation (GCV) minimum 7,1454. Faktor-faktor yang mempengaruhi AHH dan AKB adalah persentase keluarga menerapkan Perilaku Hidup Bersih dan Sehat (PHBS), persentase bayi diberi Air Susu Ibu (ASI) usia 0-6 bulan, laju pertumbuhan ekonomi, persentase persalinan yang dibantu oleh tenaga medis dan persentase penduduk miskin.
\end{abstract}

Kata Kunci : Regresi Nonparametrik, Spline Birespon, GCV, Angka harapan hidup, Angka kematian bayi

\begin{abstract}
This study used a biresponse nonparametric regression model with a spline truncated approach. The model is used to solve the problem of regression analysis where the curve shape is unknown. The truncated spline approach has a segmented polynomial function which provides flexibility. The data used in this study consisted of two response variables, namely Infant Life Expectancy (ILE) and Infant Mortality Rate (IMR) in Kalimantan. The aim of this research is to determine the nonparametric regression model of spline truncated biresponse on ILE and IMR data and to know the factors that influence ILE and IMR. The results showed that the best model is the nonparametric regression model of biresponse linear spline with $R^{2}$ value of 80,51 percent and the three-point knot spline model with a minimum Generalized Cross Validation (GCV) value of 7,1454. The factors that influence ILE and IMR are the percentage of families implementing Clean and Healthy Behavior, the percentage of babies given breast milk aged 0-6 months, the rate of economic growth, the percentage of deliveries assisted by medical personnel and the percentage of the population poor.
\end{abstract}

Keywords: GCV, Infant Life Expectancy, Infant Mortality Rate, Nonparametric Regression, Spline Birespon

Article info:

Submitted: $23^{\text {rd }}$ December 2020 Accepted: $06^{\text {th }}$ April 2021

How to cite this article:

A. B. Padatuan, S. Sifriyani, and S. Prangga, "PEMODELAN ANGKA HARAPAN HIDUP DAN ANGKA KEMATIAN BAYI DI KALIMANTAN DENGAN REGRESI NONPARAMETRIK SPLINE BIRESPON”, BAREKENG: J. Il. Mat. \& Terapan, vol. 15, no. 02, pp. 283296, Jun. 2021.

This work is licensed under a Creative Commons Attribution-ShareAlike 4.0 International License.

Copyright $\odot 2021$ Aprianti Boma Padatuan, Sifriyani, Surya Prangga 


\section{PENDAHULUAN}

Derajat kesehatan masyarakat yang tinggi dapat digunakan sebagai indikator keberhasilan program kesehatan dan program pembangunan sosial ekonomi yang secara tak langsung dapat meningkatkan angka harapan hidup. Angka harapan hidup ( $\mathrm{AHH})$ adalah rata-rata tahun hidup yang masih akan dijalani oleh seseorang yang telah berhasil mencapai umur tertentu pada suatu tahun tertentu, dalam situasi mortalitas yang berlaku di lingkungan masyarakatnya. Banyak hal yang melatarbelakangi angka harapan hidup di suatu daerah pada posisi tinggi atau rendah. Keberhasilan program kesehatan dan pembangunan sosial ekonomi pada umumnya dapat dilihat pada peningkatan pelayanan kesehatan, perilaku hidup bersih dan sehat (PHBS), pendidikan, dan pendapatan yang digambarkan dalam Pendapatan Domestik Regional Bruto (PDRB) [1].

Indikator lain yang dapat menunjukkan peningkatan derajat kesehatan manusia di suatu wilayah adalah angka kematian bayi. Angka Kematian Bayi (AKB) menunjukkan banyaknya kematian bayi usia 0 tahun dari setiap 1000 kelahiran hidup pada tahun tertentu dengan kata lain merupakan probabilitas bayi meninggal sebelum mencapai usia satu tahun. Dengan demikian AKB merupakan indikator yang penting untuk mencerminkan derajat kesehatan di masyarakat dan merupakan tolak ukur yang sensitif dari semua intervensi yang telah dilakukan pemerintah dalam menangani permasalahan kesehatan [2].

Terdapat banyak faktor yang mempengaruhi tingkat angka kematian bayi (AKB), antara lain faktor ibu dimana pentingnya pemberian ASI untuk bayi yakni mendapat nutrisi dan enzim terbaik yang dibutuhkan, bayi mendapat imun sehingga akan lebih jarang sakit [3], selanjutnya, faktor bayi, kondisi sosial ekonomi dan pelayanan kesehatan. Kemiskinan juga berhubungan dengan angka kematian bayi. Bayi dalam rumah tangga termiskin umumnya memiliki angka kematian lebih dari dua kali lipat dari angka kematian di kelompok yang paling sejahtera. Hal ini karena rumah tangga yang lebih kaya memiliki akses yang lebih banyak ke pelayanan kesehatan dan sosial yang berkualitas, praktek-praktek kesehatan yang lebih baik dan pada umumnya tingkat pendidikan yang lebih tinggi. Tingginya angka kematian bayi dapat dicegah melalui pelayanan kesehatan ibu dan bayi baru lahir yang berkualitas [4].

AHH dan AKB merupakan dua hal yang saling berhubungan, khususnya dalam hal derajat kesehatan manusia. Di pulau Kalimantan, AHH cenderung meningkat setiap tahunnya sementara AKB cenderung menurun setiap tahunnya, sehingga menunjukkan hal yang positif terhadap peningkatan derajat kesehatan masyarkatnya, untuk itu perlu dilakukan penelitian untuk mengetahui faktor-faktor apa saja yang mempengaruhinya sehingga dapat memberikan informasi kepada pemerintah setempat untuk mempertahankan dan bahkan dapat meningkatkan kesejahteraan masyrakatnya.

Pemodelan dalam metode statistika salah satunya adalah Analisis Regresi. Analisis regresi merupakan salah satu metode yang digunakan untuk mengetahui pola hubungan antara variabel yang mempengaruhi (prediktor) dengan variabel yang dipengaruhi (varibel respon) [5]. Inti dari analisis regresi adalah bagaimana menjelaskan dugaan tentang adanya hubungan kausal antara variabel prediktor dengan variabel respon. Analisis regresi juga mampu menggambarkan perpencaran titik di sekitar kurva [6]. Apabila suatu data yang akan dianalisis mempunyai pola data mengikuti pola tertentu, maka pendekatan regresi parametrik tepat digunakan untuk penyelesaiannya. Sebaliknya jika pola data sebagian mengikuti pola tertentu dan sebagian lagi tidak mengikuti pola tertentu maka pendekatan regresi semiparametrik dapat digunakan.

Pendekatan model regresi nonparametrik digunakan jika bentuk kurva regresi yang terjadi sangat fleksibel dalam mendekati pola data, serta tidak menuntut terpenuhinya asumsi-asumsi klasik seperti pada regresi parametrik (bentuk kurva regresi diketahui) atau informasi tentang bentuk pola data dimasa lalu tidak lengkap [7]. Dalam pendekatan regresi nonparametrik data diharapkan mencari sendiri bentuk estimasinya sendiri tanpa harus dipengaruhi oleh faktor subyektifitas peneliti, sehingga pendekatan regresi nonparametrik memiliki fleksibilitas yang tinggi. Dalam semua estimasi fungsi yang ada, estimator spline merupakan metode yang paling banyak mendapat perhatian dari peneliti dalam beberapa tahun terakhir. Regresi nonparametrik yang paling sering digunakan adalah regresi nonparametrik spline. Pendekatan spline mempunyai kelebihan diantaranya model cenderung mencari sendiri estimasinya kemanapun data tersebut bergerak [8]

Selain dengan optimasi PLS, Budiantara (2005) telah mengembangkan estimator spline dalam regresi nonparametrik dengan menggunakan basis fungsi keluarga spline truncated. Pendekatan ini memberikan perhitungan matematika yang relatif lebih mudah dan sederhana, yaitu dengan optimasi tanpa 
melibatkan penalty antara lain dengan optimasi least square (LS) [9]. Dalam analisis regresi nonparametrik spline jika terdapat satu variabel respon satu variabel prediktor, maka dinamakan regresi nonparametrik spline univariabel. Jika dalam analisis regresi terdapat satu variabel respon dengan variabel prediktor lebih dari satu, maka regresi tersebut dinamakan regresi nonparametrik spline multivariabel.

Regresi birespon didefinisikan sebagai salah satu model regresi yang memiliki variabel respon lebih dari satu buah dan diantara variabel-variabel tersebut terdapat korelasi atau hubungan yang kuat, baik secara logika maupun matematis [10]. Jika regresi birespon memiliki kurva regresi yang tidak diketahui, maka pendekatan yang digunakan adalah regresi nonparametrik birespon. Fungsi yang digunakan dalam pendekatan nonparametrik adalah fungsi spline dengan melibatkan banyak variabel prediktor, maka model tersebut dinamakan model regresi nonparametrik spline birespon multivariabel.

Berdasarkan definisi regresi birespon yaitu regresi dengan variabel respon sebanyak dua dan diantara variabel-variabel respon harus memiliki korelasi antara satu dengan yang lainnya. Sebelum melakukan pemodelan, terlebih dahulu harus diketahui seberapa besar hubungan atau korelasi antar variabel-variabel tersebut. Model regresi spline terbaik diperoleh dengan pemilihan titik knot $k_{1}, k_{2}, \ldots, k_{p}$ yang optimal. Pemilihan titik knot optimal ini sangat penting untuk memperoleh estimator spline terbaik yang paling sesuai dengan data. Titik knot adalah titik perpaduan bersama yang menunjukan terjadinya perubahan pola perilaku data. Titik knot merupakan suatu titik fokus dalam fungsi spline, sehingga kurva yang dibentuk tersegmen pada titik-titik tersebut

Hal penting dalam estimator spline adalah mencari estimator yang paling sesuai untuk sekumpulan data, untuk itu perlu dipilih parameter penghalus yang optimal agar diperoleh estimator spline yang paling sesuai dengan data. Wahba (1990) memberikan suatu metode yang sangat baik untuk memilih parameter penghalus yang optimal yaitu dengan metode generalized cross validation (GCV) [11]

Salah satu tujuan dari analisis regresi adalah memperoleh pola hubungan yang signifikan atau nyata antara variabel respon dengan variabel prediktor. Terdapat beberapa kriteria yang digunakan untuk menentukan model regresi terbaik, untuk penelitian ini membatasi menggunakan kriteria pemilihan model terbaik dengan menggunakan nilai GCV minimum.

Koefisien determinasi adalah nilai dari proporsi keragaman total disekitar nilai tengah $\bar{y}$ yang dijelaskan dari model regresi [12].

\section{METODE PENELITIAN}

\subsection{Data Penelitian}

Data penelitian adalah data AHH dan AKB dari 41 Kabupaten/Kota Kalimantan. Variabel yang digunakan dalam penelitian ini terdiri dari variabel respon dan variabel prediktor sebagai berikut:
a. $\quad\left(y_{1}\right)$ : Angka Harapan Hidup (tahun) [13]
b. $\quad\left(y_{2}\right)$ : Angka Kematian Bayi (per 1.000 kelahiran) [13]
c. $\left(t_{1}\right)$ : Persentase keluarga ber-PHBS (\%) [14]
d. $\left(t_{2}\right)$ : Persentase bayi diberi ASI usia 0-6 Bulan (\%) [15]
e. $\left(t_{4}\right)$ : Persentase persalinan yang dibantu oleh tenaga medis (NAKES) [15]
f. $\quad\left(t_{5}\right)$ : Persentase penduduk miskin [13]

\subsection{Tahapan Analisis}

1. Mendefinisikan variabel respon dan variabel prediktor yang diduga mempengaruhi

2. Membuat statistika deskriptif variabel respon dan variabel prediktor.

3. Melakukan pengujian korelasi antar variabel-variabel respon, dalam penelitian ini akan menggunakan korelasi Pearson. Adapun persamaan yang akan digunakan adalah sebagai berikut:

$$
r\left(y_{1}, y_{2}\right)=\frac{\operatorname{cov}\left(y_{1}, y_{2}\right)}{\left\{\operatorname{Var}\left(y_{1}\right) \operatorname{Var}\left(y_{2}\right)\right\}}
$$

4. Melakukan pengujian linieritas menggunakan scatter plot antara masing-masing variabel prediktor terhadap masing-masing variabel respon. 
5. Memodelkan angka harapan hidup dan angka kematian bayi dengan spline linier 1 knot, 2 knot dan 3 knot. Adapun persamaan yang akan digunakan adalah sebagai berikut:

$$
\begin{aligned}
& f\left(t_{i j}\right)=\sum_{j=1}^{l} \sum_{h=1}^{m} \theta_{h j} t_{i j}^{h}+\sum_{j=1}^{l} \sum_{k=1}^{r} \phi_{m+k ; j}\left(t_{i j}-k_{k j}\right)_{+}^{m} \text { dan } \\
& g\left(t_{i j}\right)=\sum_{j=1}^{l} \sum_{h=1}^{m} \psi_{h j} t_{i j}^{h}+\sum_{j=1}^{l} \sum_{k=1}^{r} \tau_{m+k ; j}\left(t_{i j}-\lambda_{k j}\right)_{+}^{m}
\end{aligned}
$$

Model regresi nonparametrik spline birespon multivariabel dapat menggunakan metode WLS (Weighted Least square) dapat dituliskan dalam bentuk matriks sebagai berikut:

$$
\begin{gathered}
\mathbf{y}=\mathbf{T} \boldsymbol{\beta}+\boldsymbol{\varepsilon} \\
\mathbf{y}=\left(\begin{array}{c}
y_{1-n} \\
--- \\
y_{2-n}
\end{array}\right)=\left(\begin{array}{c}
y_{1-1} \\
y_{1-2} \\
\vdots \\
y_{1-n} \\
--- \\
y_{2-1} \\
y_{-2} \\
\vdots \\
y_{2-n}
\end{array}\right) \quad \text { dan } \quad \mathbf{T}=\left(\begin{array}{ccc}
C & \vdots & 0 \\
\cdots & \cdots & \cdots \\
0 & \vdots & D
\end{array}\right),
\end{gathered}
$$

dengan:

$$
\begin{aligned}
& \mathbf{C}=\left(\begin{array}{cccccccccccccc}
t_{11}^{1} & \cdots & t_{11}^{m} & \left(t_{11}-k_{1}^{1}\right)_{+}^{m} & \cdots & \left(t_{11}-k_{r}^{1}\right)_{+}^{m} & \cdots & t_{q 1}^{1} & \cdots & t_{q 1}^{m} & \left(t_{q 1}-k_{1}^{1}\right)_{+}^{m} & \cdots & \left(t_{q 1}-k_{r}^{1}\right)_{+}^{m} \\
t_{12}^{1} & \cdots & t_{12}^{m} & \left(t_{12}-k_{1}^{1}\right)_{+}^{m} & \cdots & \left(t_{12}-k_{r_{+}^{1}}^{1}\right. & \cdots & t_{q 2}^{1} & \cdots & t_{q 2}^{m} & \left(t_{q 2}-k_{1}^{1}\right)_{+}^{m} & \cdots & \left(t_{q 1}-k_{r}^{1}\right)_{+}^{m} \\
\vdots & \vdots & \vdots & \vdots & \vdots & \vdots & \vdots & \vdots & \vdots & \vdots & \vdots & \vdots & \vdots \\
t_{1 n}^{1} & \cdots & t_{1 n}^{m} & \left(t_{1 n}-k_{1}^{1}\right)_{+}^{m} & \cdots & \left(t_{1 n}-k_{r}^{1}\right)_{+}^{m} & \cdots & t_{q n}^{1} & \cdots & t_{q n}^{m} & \left(t_{q n}-k_{1}^{1}\right)_{+}^{m} & \cdots & \left(t_{q 1}-k_{r}^{1}\right)_{+}^{m}
\end{array}\right) \\
& \mathbf{D}=\left(\begin{array}{ccccccccccccc}
t_{11}^{1} & \cdots & t_{11}^{p} & \left(t_{11}-\lambda_{1}^{1}\right)_{+}^{m} & \cdots & \left(t_{11}-\lambda_{r}^{1}\right)_{+}^{m} & \cdots & t_{q 1}^{1} & \cdots & t_{q 1}^{p} & \left(t_{q 1}-\lambda_{1}^{1}\right)_{+}^{m} & \cdots & \left(t_{q 1}-\lambda_{r}^{1}\right)_{+}^{m} \\
t_{12}^{1} & \cdots & t_{12}^{p} & \left(t_{12}-\lambda_{1}^{1}\right)_{+}^{m} & \cdots & \left(t_{12}-\lambda_{r}^{1}\right)_{+}^{m} & \cdots & t_{q 2}^{1} & \cdots & t_{q 2}^{p} & \left(t_{q 2}-\lambda_{1}^{1}\right)_{+}^{m} & \cdots & \left(t_{q 1}-\lambda_{r}^{1}\right)_{+}^{m} \\
\vdots & \vdots & \vdots & \vdots & \vdots & \vdots & \vdots & \vdots & \vdots & \vdots & \vdots & \vdots & \vdots \\
t_{1 n}^{1} & \cdots & t_{1 n}^{p} & \left(t_{1 n}-\lambda_{1}^{1}\right)_{+}^{m} & \cdots & \left(t_{1 n}-\lambda_{r}^{1}\right)_{+}^{m} & \cdots & t_{q n}^{1} & \cdots & t_{q n}^{p} & \left(t_{q n}-\lambda_{1}^{1}\right)_{+}^{m} & \cdots & \left(t_{q 1}-\lambda_{r}^{1}\right)_{+}^{m}
\end{array}\right)
\end{aligned}
$$

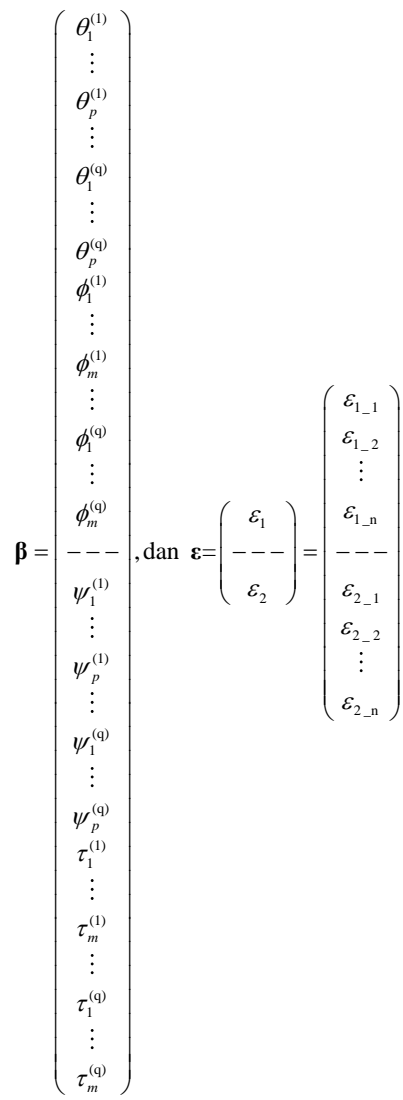

sedangkan matrik $\mathbf{0}$ adalah matrik dengan elemen-elemennya null yang berukuran $n \times(q(p+m))$. Untuk nilai $\boldsymbol{\beta}$ dan $\boldsymbol{\varepsilon}$ merupakan vektor parameter dan vektor random eror yang memiliki elemen seperti pada persamaan (3).

Untuk menghitung estimasi parameter pada regresi nonparametrik spline birespon dapat dilakukan dengan melakukan optimasi Weighted Least Square (WLS). Penentuan matriks pembobot W dalam kasus ini yaitu dengan perhitungan nilai varian kovarian dari respon pertama dan respon kedua [9] sehingga diperoleh matriks $\mathbf{W}$ sebagai berikut:

$$
\begin{aligned}
\mathbf{W}_{\left(\mathrm{y}_{1}, y_{2}\right)} & =\left[\begin{array}{ccc|cccc}
\operatorname{var}\left(\mathrm{y}_{1}\right) & \operatorname{kov}\left(\mathrm{y}_{1}, \mathrm{y}_{2}\right) \\
\operatorname{kov}\left(\mathrm{y}_{1}, \mathrm{y}_{2}\right) & \operatorname{var}\left(\mathrm{y}_{2}\right)
\end{array}\right] \\
& =\left|\begin{array}{ccccccccc}
\sigma_{1}^{2} & 0 & \cdots & 0 & \sigma_{11} & 0 & \cdots & 0 \\
0 & \sigma_{1}^{2} & & \vdots & 0 & \sigma_{22} & & \vdots \\
\vdots & & \ddots & 0 & \vdots & & \ddots & 0 \\
0 & \cdots & 0 & \sigma_{1}^{2} & 0 & \cdots & 0 & \sigma_{n n} \\
--0------ & ---c & \\
\sigma_{11} & 0 & \cdots & 0 & \sigma_{2}^{2} & 0 & \cdots & 0 \\
0 & \sigma_{22} & \vdots & 0 & \sigma_{2}^{2} & & \vdots \\
\vdots & & \ddots & 0 & \vdots & & \ddots & 0 \\
0 & \cdots & 0 & \sigma_{n n} & 0 & \cdots & 0 & \sigma_{2}^{2}
\end{array}\right|
\end{aligned}
$$

Sehingga bentuk estimasi model spline dalam regresi nonparametrik birespon menjadi sebagai berikut: 


$$
\begin{aligned}
& \mathbf{y}=\mathbf{T} \beta \\
& \mathbf{y}=\mathbf{T}\left(\mathbf{T}^{\mathrm{T}} W \mathbf{T}\right)^{-1} \mathbf{T}^{\mathrm{T}} \mathbf{W} \mathbf{y}
\end{aligned}
$$

6. Memilih titik knot optimal dengan menggunakan metode Generalized Cross Validation (GCV) dimana nilai GCV terkecil dengan titik knot optimal. Penentuan titik knot menggunakan rumus sebagai berikut:

$$
\text { knot } s_{i}=\frac{(b-a) \times i}{(k+1)} \times a ; i=1,2, \ldots, k
$$

$a$ merupakan nilai minimum data, $b$ adalah nilai maksimum data. Cara terakhir adalah penentuan menggunakan seleksi knot. Knot dipilih menggunakan seluruh data sebagai kandidat knot. Selanjutkan dilakukan pemilihan titik knot optimal menggunakan GCV:

$$
G C V=\frac{\operatorname{MSE}(k)}{\left[n^{-1} \operatorname{trace}(\mathbf{I}-\mathbf{A}(\mathbf{k}))\right]^{2}}
$$

7. Menghitung nilai $R^{2}$ dari model dengan masing-masing titik knot yang dihasilkan dengan menggunakan persamaan sebagai berikut:

$$
R^{2}=\frac{\sum_{i=1}^{n}\left(\hat{y}_{i}-\bar{y}\right)^{2}}{\sum_{i=1}^{n}\left(y_{i}-\bar{y}\right)^{2}}
$$

8. Memodelkan angka harapan hidup dan angka kematian bayi menggunakan spline dengan titik knot optimal.

9. Melakukan interpretasi model dan menarik kesimpulan.

\section{HASIL DAN PEMBAHASAN}

Sebelum melakukan pemodelan, maka akan dicari terlebih dahulu karakteristik dari variabel-variabel yang digunakan dalam penelitian ini untuk dapat dilihat pada tabel 1. Penelitian ini mengambil unit observasi yaitu kabupaten/kota di keempat Provinsi yang terdapat di Pulau Kalimantan. Jumlah unit observasi ada sebanyak $41 \mathrm{kabupaten/kota} \mathrm{dengan} \mathrm{penelitian} \mathrm{menggunakan} \mathrm{variabel} \mathrm{respon} \mathrm{dan} \mathrm{variabel}$ predictor, sebagai berikut:

Tabel 1. Statistika Deskripif

\begin{tabular}{ccccccc}
\hline Variabel & N & Rata-rata & $\begin{array}{c}\text { Nilai } \\
\text { Maksimum }\end{array}$ & $\begin{array}{c}\text { Nilai } \\
\text { Minimum }\end{array}$ & Jangkauan & $\begin{array}{c}\text { Standar } \\
\text { Deviasi }\end{array}$ \\
\hline AHH $\left(y_{1}\right)$ & 41 & 70,30 & 73,96 & 63,05 & 10,91 & 2,73 \\
\hline AKB $\left(y_{2}\right)$ & 41 & 9,99 & 24.33 & 1,18 & 23,15 & 5,78 \\
\hline $\begin{array}{c}\text { Persentase Keluarga PHBS } \\
\left(t_{1}\right)\end{array}$ & 41 & 49,30 & 89,1 & 2,3 & 86,8 & 22,28 \\
\hline $\begin{array}{c}\text { Persentase Bayi diberi ASI } \\
\text { Usia 0-6 bulan }\left(t_{2}\right)\end{array}$ & 41 & 48,55 & 95 & 4,4 & 90,6 & 23,69 \\
\hline $\begin{array}{c}\text { Laju Pertumbuhan Ekonomi } \\
\left(t_{3}\right)\end{array}$ & 41 & 4,77 & 10,4 & 0,47 & 9,93 & 2,34 \\
\hline $\begin{array}{c}\text { Persentase Persalinan } \\
\text { dibantu NAKES }\left(t_{4}\right)\end{array}$ & 41 & 82,51 & 98,4 & 62,05 & 36,35 & 9,64 \\
\hline $\begin{array}{c}\text { Persentase penduduk miskin } \\
\left(t_{5}\right)\end{array}$ & 41 & 9,36 & 30,45 & 1,35 & 29,1 & 7,42 \\
\hline
\end{tabular}

Selanjutnya membuat scatter plot antara variabel AHH dan AKB terhadap kelima variabel prediktor yang diduga berpengaruh. Dapat dilihat bahwa pola hubungan yang terbentuk antara variabel AHH dan AKB dengan kelima variabel prediktor tidak dapat diketahui. Karena pola hubungan variabel respon dan variabel prediktor tidak dapat diketahui sebagaimana ditampilkan dalam gambar 1 dan gambar 2, maka penyelesaian permasalahan yang tepat yaitu dengan pendekatan nonparametrik.

Sebelum melakukan pemodelan, terlebih dahulu harus diketahui seberapa besar hubungan linier atau korelasi antar variabel-variabel respon. Diperoleh nilai korelasi sebesar 0,61 yang artinya bahwa hubungan linier atau korelasi antar variabel-variabel responnya dikategorikan kuat. Korelasi negatif menandakan 
bahwa semakin tinggi angka harapan hidup $\left(y_{1}\right)$ maka angka kematian bayi $\left(y_{2}\right)$ akan semakin rendah, dimana diharapkan jika angka harapan hidup meningkat maka angka kematian bayi akan menurun. Selanjutnya dilakukan pengujian hipotesis untuk melihat signifikansi korelasi antara AHH dan AKB, didapatkan nilai $p$-value sebesar 0,00 sehingga dengan menggunakan taraf signifikansi $5 \%$ diperoleh $p$ value $=0,00<\alpha=0,05$ dan diputuskan untuk menolak $H_{0}$ sehingga dapat disimpulkan bahwa terdapat hubungan yang signifikan antara angka harapan hidup dan angka kematian bayi.

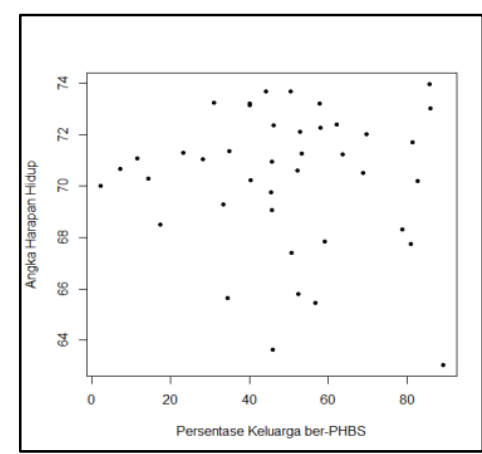

1.a. scatter plot antara $y_{l}$ dan $t_{1}$

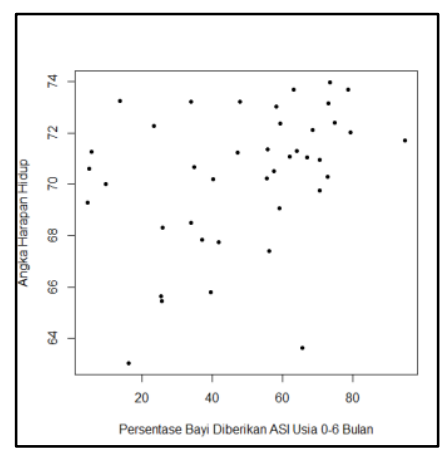

1.b. scatter plot antara $y_{1}$ dan $t_{2}$

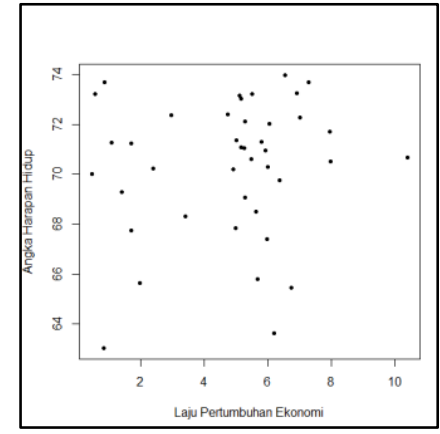

1.c. scatter plot antara $y_{l}$ dan $t_{3}$

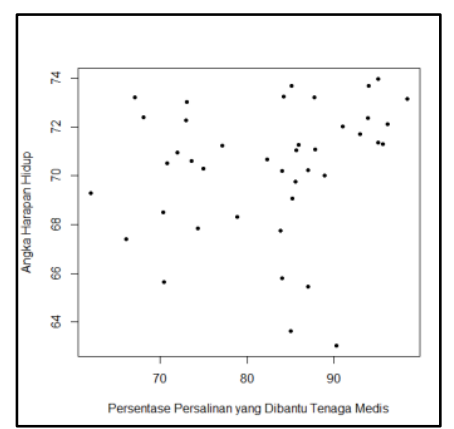

1.d. scatter plot antara $y_{l}$ dan $t_{4}$

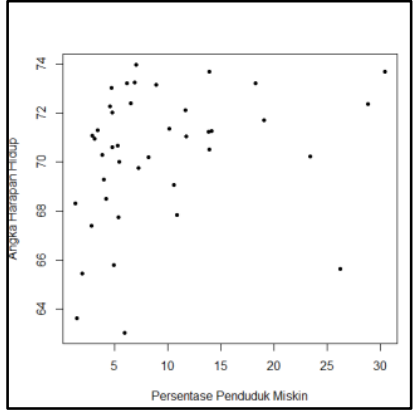

1.e. scatter plot antara $y_{1}$ dan $t_{5}$

Gambar 1. Scatter Plot antara Variabel AHH dan Variabel Prediktor 


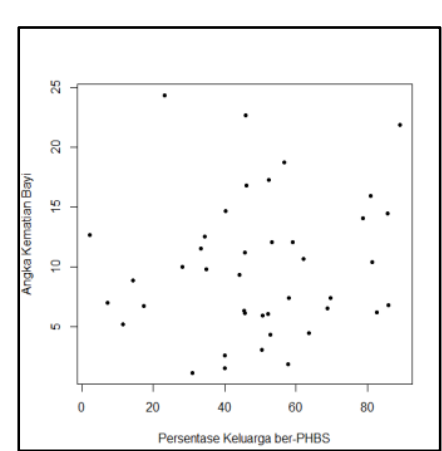

2.a. scatter plot antara $y_{2}$ dan $t_{1}$

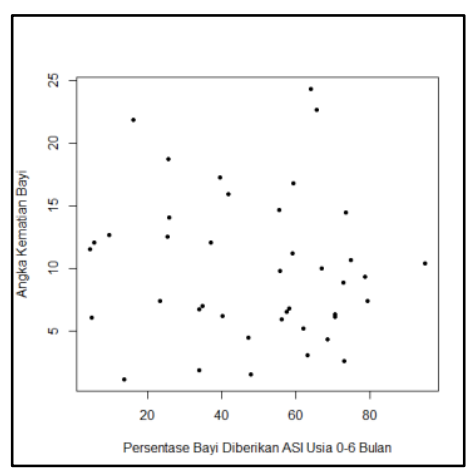

2.b. scatter plot antara $y_{2}$ dan $t_{2}$

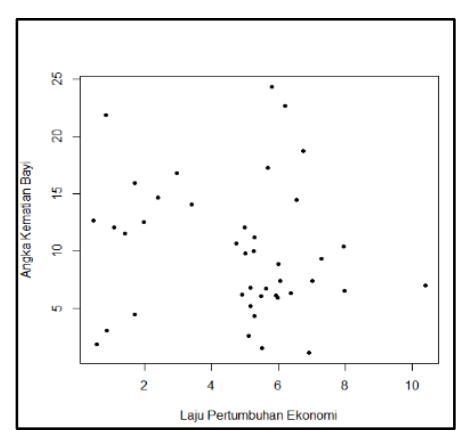

2.c. scatter plot antara $y_{2}$ dan $t_{3}$

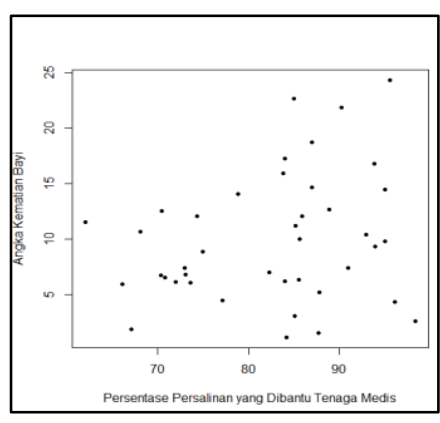

2.d. scatter plot antara $y_{2}$ dan $t_{4}$

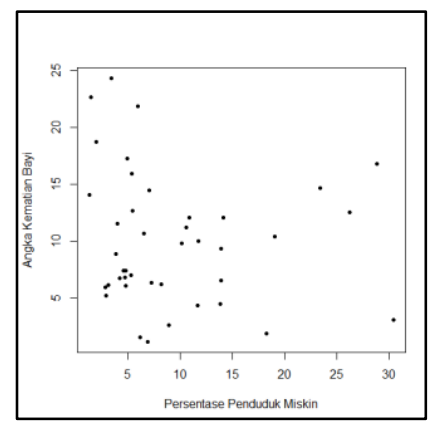

2.e. scatter plot antara $y_{2}$ dan $t_{5}$

Gambar 2. Scatter Plot antara Variabel AKB dan Variabel Prediktor

\subsection{Pemodelan Regresi Nonparametrik Spline Birespon}

Pendekatan regresi nonparametrik spline birespon pada penelitian ini akan menggunakan 1 titik knot, 2 titik knot dan 3 titik knot. Pemilihan model terbaik dari regresi spline birespon dapat dilihat dari nilai GCV yang paling minimum dan nilai $R^{2}$ yang paling maksimum. Pada tabel 2 menunjukkan nilai GCV dan nilai $R^{2}$ dari masing-masing titik knot.

Tabel 2 Nilai GCV Minimum Masing-masing Titik Knot

\begin{tabular}{ccc}
\hline Titik Knot & GCV Minimum & $R^{2}$ \\
\hline 1 Titik Knot & 8,0649 & 33,9676 \\
\hline 2 Titik Knot & 7,3700 & 16,1128 \\
\hline 3 Titik Knot & $\mathbf{7 , 1 4 5 4}$ & $\mathbf{8 0 , 5 0 6 4}$ \\
\hline
\end{tabular}

Model regresi nonparametrik spline birespon pada penelitian ini yang memiliki nilai GCV terkecil yaitu pada tiga titik knot sebesar 7,1454 dan nilai $R^{2}$ maksimum sebesar $80,5064 \%$. Hal ini berarti model dengan tiga titik knot merupakan model regresi nonparametrik spline birespon terbaik.

Tabel 3 Posisi Titik Knot Optimal dengan Tiga Titik Knot

\begin{tabular}{ccc}
\hline $\begin{array}{c}\text { Variabel } \\
\text { Prediktor }\end{array}$ & $\begin{array}{c}\text { Titik Knot Optimal } \\
\text { Respon 1 }\end{array}$ & $\begin{array}{c}\text { Titik Knot } \\
\text { Optimal Respon 2 }\end{array}$ \\
\hline \multirow{3}{*}{$t_{1}$} & 8,2862 & 62,1620 \\
\cline { 2 - 3 } & 29,2379 & 65,1551 \\
\cline { 2 - 3 } & 86,1069 & 74,1344 \\
\hline \multirow{3}{*}{$t_{2}$} & 10,6482 & 66,8827 \\
\cline { 2 - 3 } & 32,5172 & 70,0069 \\
\hline \multirow{3}{*}{$t_{3}$} & 91,8758 & 79,3793 \\
\hline & 1,1548 & 7,3182 \\
\hline & 3,5517 & 7,6606 \\
\hline
\end{tabular}




\begin{tabular}{ccc}
\hline \multirow{2}{*}{$t_{4}$} & 73,3310 & 88,3724 \\
\cline { 2 - 3 } & 97,1465 & 92,1327 \\
\hline \multirow{3}{*}{$t_{5}$} & 3,3568 & 21,4189 \\
\cline { 2 - 3 } & 10,3810 & 22,4224 \\
\cline { 2 - 3 } & 29,4465 & 25,4327 \\
\hline
\end{tabular}

Adapun parameter yang akan digunakan sebanyak 20 parameter untuk respon pertama dan 20 parameter untuk respon kedua. Berikut estimasi parameternya:

Tabel 4. Hasil Estimasi Parameter dengan Tiga Titik Knot

\begin{tabular}{|c|c|c|c|c|}
\hline \multirow{2}{*}{$\begin{array}{l}\text { Variabel } \\
\text { Prediktor }\end{array}$} & \multicolumn{2}{|c|}{ Variabel Respon 1} & \multicolumn{2}{|c|}{ Variabel Respon 2} \\
\hline & $\hat{\theta}$ & $\hat{\phi}$ & $\hat{\psi}$ & $\hat{\tau}$ \\
\hline \multirow{3}{*}{$t_{1}$} & \multirow{3}{*}{2,1813} & $-2,2916$ & \multirow{3}{*}{0,0774} & $-6,0439$ \\
\hline & & 0,1632 & & 6,1505 \\
\hline & & $-5,1328$ & & 0,7810 \\
\hline \multirow{3}{*}{$t_{2}$} & \multirow{3}{*}{0,8413} & $-1,2071$ & \multirow{3}{*}{0,0850} & $-1,9509$ \\
\hline & & 0,4599 & & 2,8728 \\
\hline & & $-1,0664$ & & $-2,2468$ \\
\hline \multirow{3}{*}{$t_{3}$} & \multirow{3}{*}{$-12,8819$} & 14,3202 & \multirow{3}{*}{$-3,0388$} & 61,8769 \\
\hline & & $-2,0004$ & & $-22,2526$ \\
\hline & & 18,0560 & & $-69,2209$ \\
\hline \multirow{3}{*}{$t_{4}$} & \multirow{3}{*}{$-1,0862$} & 1,1757 & \multirow{3}{*}{0,5461} & $-18,7592$ \\
\hline & & $-0,0425$ & & 27,8907 \\
\hline & & 0,4263 & & $-13,2474$ \\
\hline \multirow{3}{*}{$t_{5}$} & \multirow{3}{*}{2,9452} & $-2,8638$ & \multirow{3}{*}{$-1,4888$} & 6,1468 \\
\hline & & $-0,0903$ & & 2,2983 \\
\hline & & 0,8063 & & $-12,8599$ \\
\hline
\end{tabular}

Setelah diperoleh posisi titik knot untuk masing-masing variabel dan juga nilai parameter dari model linier tiga titik knot, maka model spline birespon tiga titik knot dapat dituliskan ke dalam bentuk persamaan sebagai berikut:

$$
\begin{aligned}
\hat{y}_{1}= & 2,1813 t_{1}-2,2916\left(t_{1}-8,2862\right)_{+}+0,1632\left(t_{1}-29,2379\right)_{+}-5,1328\left(t_{1}-86,1069\right)_{+}+0,8413 t_{2}-1,2071\left(t_{2}-10,6482\right)_{+} \\
& +0,4599\left(t_{2}-32,5172\right)_{+}-1,0664\left(t_{2}-91,8758\right)_{+}-12,8819 t_{3}+14,3202\left(t_{3}-1,1548\right)_{+}-2,0004\left(t_{3}-3,5517\right)_{+} \\
& +18,0560\left(t_{3}-10,0575\right)_{+}-1,0862 t_{4}+1,1757\left(t_{4}-64,5569\right)_{+}-0,0425\left(t_{4}-73,3310\right)_{+}+0,4263\left(t_{4}-97,1465\right)_{+} \\
& +2,9452 t_{5}-2,8638\left(t_{5}-3,3568\right)_{+}-0,0903\left(t_{5}-10,3810\right)_{+}+0,8063\left(t_{5}-29,4465\right)_{+} \\
\hat{y}_{2}= & 0,0774 t_{1}-6,0439\left(t_{1}-62,1620\right)_{+}+6,1505\left(t_{1}-65,1551\right)_{+}+0,7810\left(t_{1}-74,1344\right)_{+}+0,0850 t_{2}-1,9509\left(t_{2}-66,8827\right)_{+} \\
& +2,8728\left(t_{2}-70,0069\right)_{+}-2,2468\left(t_{2}-79,3793\right)_{+}-3,0388 t_{3}+61,8769\left(t_{3}-7,3182\right)_{+}-22,2526\left(t_{3}-7,6606\right)_{+} \\
& -69,2209\left(t_{3}-8,6879\right)_{+}+0,5461 t_{4}-18,7592\left(t_{4}-87,1189\right)_{+}+27,8907\left(t_{4}-88,3724\right)_{+}-13,2474\left(t_{4}-92,1327\right)_{+} \\
& -1,4888 t_{5}+6,1468\left(t_{5}-21,4189\right)_{+}+2,2983\left(t_{5}-22,4224\right)_{+}-12,8599\left(t_{5}-25,4327\right)_{+}
\end{aligned}
$$

\subsection{Interpretasi Model dan Faktor-faktor yang Mempengaruhi}

Pemodelan Angka Harapan Hidup (AHH) dan Angka Kematian Bayi (AKB) terbaik dengan menggunakan pendekatan regresi nonparametrik spline birespon adalah model regresi nonparametrik spline birespon dengan tiga titik knot.

\subsubsection{Interpretasi untuk model spline variabel respon pertama}

1. Jika variabel dari $t_{2}, t_{3}, t_{4}$ dan $t_{5}$ konstan maka pengaruh dari faktor persentase keluarga ber-PHBS $\left(t_{1}\right)$ terhadap Angka Harapan Hidup $\left(y_{1}\right)$ adalah sebagai berikut: 


$$
\begin{aligned}
\hat{y}_{1}= & 2,1813 t_{1}-2,2916\left(t_{1}-8,2862\right)_{+}+0,1632\left(t_{1}-29,2379\right)_{+} \\
& -5,1328\left(t_{1}-86,1069\right)_{+} \\
& = \begin{cases}2,1813 t_{1} & ; t_{1}<8,2862 \\
-0,1103 t_{1}+18,9886 & ; 8,2862 \leq t_{1}<29,2379 \\
0,0529 t_{1}+14,2170 & ; 29,2379 \leq t_{1}<86,1069 \\
-5,0799 t_{1}-456,1865 & ; t_{1} \geq 86,1069\end{cases}
\end{aligned}
$$

Dari model di atas menjelaskan bahwa jika saat persentase keluarga ber-PHBS kurang dari 8,2862\% maka setiap penambahan 1\% persentase keluarga ber-PHBS akan meningkatkan Angka Harapan Hidup (AHH) sebesar 2,1813 tahun. Jika persentase keluarga ber-PHBS sebesar 8,2862 sampai kurang dari 29,2379\% maka setiap kenaikan 1\% persentase keluarga ber-PHBS akan menurunkan Angka Harapan Hidup (AHH) sebesar 0,1103 tahun. Jika persentase keluarga ber-PHBS sebesar 29,2379 sampai kurang dari 86,1069\% maka setiap kenaikan 1\% persentase keluarga ber-PHBS akan meningkatkan Angka Harapan Hidup (AHH) sebesar 0,0529 tahun. Jika persentase keluarga ber-PHBS sebesar 86,1069 atau lebih maka setiap kenaikan 1\% persentase keluarga ber-PHBS akan menurunkan Angka Harapan Hidup (AHH) sebesar 5,0799 tahun.

2. Jika variabel dari $t_{1}, t_{3}, t_{4}$ dan $t_{5}$ konstan maka pengaruh dari faktor persentase bayi diberi ASI usia 0-6 bulan $\left(t_{2}\right)$ terhadap Angka Harapan Hidup $\left(y_{1}\right)$ adalah sebagai berikut :

$$
\begin{aligned}
\hat{y}_{1}= & 0,8413 t_{2}-1,2071\left(t_{2}-10,6482\right)_{+}+0,4599\left(t_{2}-32,5172\right)_{+} \\
& -1,0664\left(t_{2}-91,8758\right)_{+} \\
& = \begin{cases}0,8413 t_{2} & ; t_{2}<10,6482 \\
-0,3658 t_{2}+12,8534 & ; 10,6482 \leq t_{2}<32,5172 \\
0,0941 t_{2}-2,1012 & ; 32,5172 \leq t_{2}<91,8758 \\
-0,9723 t_{2}+95,8751 & ; t_{2} \geq 91,8758\end{cases}
\end{aligned}
$$

Dari model di atas menjelaskan bahwa jika saat persentase bayi diberi ASI usia 0-6 bulan $\left(t_{2}\right)$ kurang dari 10,6482\% maka setiap penambahan $1 \%$ persentase bayi diberi ASI usia 0-6 bulan akan meningkatkan Angka Harapan Hidup (AHH) sebesar 0,8413 tahun. Jika persentase bayi diberi ASI usia 0-6 bulan sebesar 10,6482 sampai kurang dari 32,5172\% maka setiap kenaikan $1 \%$ persentase bayi diberi ASI usia 0-6 bulan akan menurunkan Angka Harapan Hidup (AHH) sebesar 0,3658 tahun. Jika persentase bayi diberi ASI usia 0-6 bulan sebesar 32,5172 sampai kurang dari 91,8758\% maka setiap kenaikan $1 \%$ persentase bayi diberi ASI usia 0-6 bulan akan meningkatkan Angka Harapan Hidup (AHH) sebesar 0,0941 tahun. Jika persentase bayi diberi ASI usia 0-6 bulan sebesar 91,8758\% atau lebih maka setiap kenaikan $1 \%$ persentase bayi diberi ASI usia 0-6 bulan akan menurunkan Angka Harapan Hidup (AHH) sebesar 0,9723 tahun.

3. Jika variabel dari $t_{1}, t_{2}, t_{4}$ dan $t_{5}$ konstan maka pengaruh dari faktor laju pertumbuhan ekonomi

$t_{3}$ ) terhadap Angka Harapan Hidup ( $\left.y_{1}\right)$ adalah sebagai berikut :

$$
\begin{aligned}
\hat{y}_{1}= & -12,8819 t_{3}+14,3202\left(t_{3}-1,1548\right)_{+}-2,0004\left(t_{3}-3,5517\right)_{+} \\
& +18,0560\left(t_{3}-10,0575\right)_{+} \\
& = \begin{cases}-12,8819 t_{3} & ; t_{3}<1,1548 \\
1,4383 t_{3}-16,5369 & ; 1,1548 \leq t_{3}<3,5517 \\
-0,5621 t_{3}-9,5015 & ; 3,5517 \leq t_{3}<10,0575 \\
17,4939 t_{3}-191,0997 & ; t_{3} \geq 10,0575\end{cases}
\end{aligned}
$$

Dari model di atas menjelaskan bahwa jika saat laju pertumbuhan ekonomi $\left(t_{3}\right)$ kurang dari $1,1548 \%$ maka setiap penambahan $1 \%$ laju pertumbuhan ekonomi maka Angka Harapan Hidup (AHH) cenderung menurun sebesar 12,8819 tahun. Jika laju pertumbuhan ekonomi sebesar 1,1548 sampai kurang dari 3,5517\% maka setiap kenaikan 1\% laju pertumbuhan ekonomi akan meningkatkan Angka Harapan Hidup (AHH) sebesar 1,4383 tahun. Jika laju pertumbuhan ekonomi sebesar 3,5517 sampai kurang dari $10,0575 \%$ maka setiap kenaikan 1\% laju pertumbuhan ekonomi maka Angka Harapan Hidup (AHH) cenderung menurun sebesar 0,5621 tahun. Jika laju pertumbuhan ekonomi sebesar 10,0575\% atau lebih 
maka setiap kenaikan 1\% laju pertumbuhan ekonomi akan meningkatkan Angka Harapan Hidup (AHH) sebesar 17,4939 tahun.

4. Jika variabel dari $t_{1}, t_{2}, t_{3}$ dan $t_{5}$ konstan maka pengaruh dari faktor persentase persalinan yang dibantu oleh tenaga medis $\left(t_{4}\right)$ terhadap Angka Harapan Hidup $\left(y_{1}\right)$ adalah sebagai berikut :

$$
\begin{aligned}
\hat{y}_{1}= & -1,0862 t_{4}+1,1757\left(t_{4}-64,5569\right)_{+}-0,0425\left(t_{4}-73,3310\right)_{+} \\
& +0,4263\left(t_{4}-97,1465\right)_{+} \\
& = \begin{cases}-1,0862 t_{4} & ; t_{4}<64,5569 \\
0,0895 t_{4}-75,8995 & ; 64,5569 \leq t_{4}<73,3310 \\
0,0470 t_{4}-72,7829 & ; 73,3310 \leq t_{4}<97,1465 \\
0,4733 t_{4}-114,1965 & ; t_{4} \geq 97,1465\end{cases}
\end{aligned}
$$

Dari model di atas menjelaskan bahwa jika persentase persalinan yang dibantu oleh tenaga medis $\left(t_{4}\right)$ kurang dari $64,5569 \%$ maka setiap penambahan $1 \%$ persentase persalinan yang dibantu oleh tenaga medis akan menurunkan Angka Harapan Hidup (AHH) sebesar 1,0862 tahun. Jika persentase persalinan yang dibantu oleh tenaga medis sebesar 64,5569 sampai kurang dari 73,3310\% maka setiap kenaikan 1\% persentase persalinan yang dibantu oleh tenaga medis akan meningkatkan Angka Harapan Hidup (AHH) sebesar 0,0895 tahun. Jika persentase persalinan yang dibantu oleh tenaga medis sebesar 73,3310 sampai kurang dari 97,1465 \% maka setiap kenaikan $1 \%$ persentase persalinan yang dibantu oleh tenaga medis akan meningkatkan Angka Harapan Hidup (AHH) sebesar 0,0470 tahun. Jika persentase persalinan yang dibantu oleh tenaga medis sebesar $97,1465 \%$ atau lebih maka setiap kenaikan 1 persentase persalinan yang dibantu oleh tenaga medis akan meningkatkan Angka Harapan Hidup (AHH) sebesar 0,4733 tahun.

5. Jika variabel dari $t_{1}, t_{2}, t_{3}$ dan $t_{4}$ konstan maka pengaruh dari faktor persentase penduduk miskin

$t_{5}$ ) terhadap Angka Harapan Hidup $\left(y_{1}\right)$ adalah sebagai berikut :

$$
\begin{aligned}
\hat{y}_{1}= & 2,9452 t_{5}-2,8638\left(t_{5}-3,3568\right)_{+}-0,0903\left(t_{5}-10,3810\right)_{+} \\
& +0,8063\left(t_{5}-29,4465\right)_{+} \\
= & \begin{cases}2,9452 t_{5} & ; t_{5}<3,3568 \\
0,0814 t_{5}-9,6132 & ; 3,3568 \leq t_{5}<10,3810 \\
-0,0903 t_{5}-8,6757 & ; 10,3810 \leq t_{5}<29,4465 \\
0,7974 t_{5}-32,4185 & ; t_{5} \geq 29,4465\end{cases}
\end{aligned}
$$

Dari model di atas menjelaskan bahwa jika persentase penduduk miskin $\left(t_{5}\right)$ kurang dari 3,3568\% maka setiap penambahan $1 \%$ persentase penduduk miskin akan meningkatkan Angka Harapan Hidup (AHH) sebesar 2,9452 tahun. Jika persentase penduduk miskin sebesar 3,3568 sampai kurang dari 10,3810\% maka setiap kenaikan $1 \%$ persentase penduduk miskin akan meningkatkan Angka Harapan Hidup (AHH) sebesar 0,0814 tahun. Jika persentase penduduk miskin sebesar 10,3810 sampai kurang dari 29,4465\% maka setiap kenaikan 1 persentase penduduk miskin akan menurunkan Angka Harapan Hidup (AHH) sebesar 0,0903 tahun. Jika persentase penduduk miskin sebesar 29,4465\% atau lebih maka setiap kenaikan $1 \%$ persentase penduduk miskin akan meningkatkan Angka Harapan Hidup (AHH) sebesar 0,7974 tahun.

\subsubsection{Interpretasi untuk model spline variabel respon kedua}

Untuk model dari variabel respon kedua yaitu Angka Kematian Bayi (AKB). Interpretasi untuk masing-masing variabel prediktor pada model spline untuk respon kedua akan diuraikan sebagai berikut:

1. Jika variabel dari $t_{2}, t_{3}, t_{4}$ dan $t_{5}$ konstan maka pengaruh dari faktor persentase keluarga ber-PHBS $\left(t_{1}\right)$ terhadap Angka Kematian Bayi ( $y_{2}$ ) adalah sebagai berikut : 


$$
\begin{aligned}
\hat{y}_{2}= & 0,0774 t_{1}-6,0439\left(t_{1}-62,1620\right)_{+}+6,1505\left(t_{1}-65,1551\right)_{+} \\
& +0,7810\left(t_{1}-74,1344\right)_{+} \\
& = \begin{cases}0,0774 t_{1} & ; t_{1}<62,1620 \\
-5,9665 t_{1}+375,7009 & ; 62,1620 \leq t_{1}<65,1551 \\
0,1840 t_{1}-25,0355 & ; 65,1551 \leq t_{1}<74,1344 \\
0,9650 t_{1}-82,9344 & ; t_{1} \geq 74,1344\end{cases}
\end{aligned}
$$

Dari model di atas menjelaskan bahwa jika saat persentase keluarga ber-PHBS kurang dari 62,1620\% maka setiap penambahan 1\% persentase keluarga ber-PHBS akan meningkatkan Angka Kematian Bayi (AKB) sebesar 0,0774 per 1000 kelahiran. Jika persentase keluarga ber-PHBS sebesar 62,1620 sampai kurang dari 65,1551\% maka setiap kenaikan 1\% persentase keluarga ber-PHBS akan menurunkan Angka Kematian Bayi (AKB) sebesar 5,9665 per 1000 kelahiran. Jika persentase keluarga ber-PHBS sebesar 65,1551 sampai kurang dari $74,1344 \%$ maka setiap kenaikan $1 \%$ persentase keluarga ber-PHBS akan meningkatkan Angka Kematian Bayi (AKB) sebesar 0,1840 per 1000 kelahiran. Jika persentase keluarga ber-PHBS sebesar 74,1344 atau lebih maka setiap kenaikan $1 \%$ persentase keluarga ber-PHBS akan meningkatkan Angka Kematian Bayi (AKB) sebesar 0,9650 per 1000 kelahiran.

2. Jika variabel dari $t_{1}, t_{3}, t_{4}$ dan $t_{5}$ konstan maka pengaruh dari faktor persentase bayi diberi ASI usia 0-6 bulan $\left(t_{2}\right)$ terhadap Angka Kematian Bayi $\left(y_{2}\right)$ adalah sebagai berikut :

$$
\begin{aligned}
\hat{y}_{2}= & 0,0850 t_{2}-1,9509\left(t_{2}-66,8827\right)_{+}+2,8728\left(t_{2}-70,0069\right)_{+} \\
& -2,2468\left(t_{2}-79,3793\right)_{+} \\
& = \begin{cases}0,0850 t_{2} & ; t_{2}<66,8827 \\
-1,8659 t_{2}+130,4814 & ; 66,8827 \leq t_{2}<70,0069 \\
1,0069 t_{2}-70,6343 & ; 70,0069 \leq t_{2}<79,3793 \\
-1,2399 t_{2}+107,7150 & ; t_{2} \geq 79,3793\end{cases}
\end{aligned}
$$

Dari model di atas menjelaskan bahwa jika saat persentase bayi diberi ASI usia 0-6 bulan $\left(t_{2}\right)$ kurang dari $66,8827 \%$ maka setiap penambahan $1 \%$ persentase bayi diberi ASI usia 0-6 bulan akan meningkatkan Angka Kematian Bayi (AKB) sebesar 0,0850 per 1000 kelahiran. Jika persentase bayi diberi ASI usia 0-6 bulan sebesar 66,8827 sampai kurang dari 70,0069\% maka setiap kenaikan $1 \%$ persentase bayi diberi ASI usia 0-6 bulan akan menurunkan Angka Kematian Bayi (AKB) sebesar 1,8659 per 1000 kelahiran. Jika persentase bayi diberi ASI usia 0-6 bulan sebesar 70,0069 sampai kurang dari 79,3793\% maka setiap kenaikan $1 \%$ persentase bayi diberi ASI usia 0-6 bulan akan meningkatkan Angka Kematian Bayi (AKB) sebesar 1,0069 per 1000 kelahiran. Jika persentase bayi diberi ASI usia 0-6 bulan sebesar 79,3793\% atau lebih maka setiap kenaikan 1\% persentase bayi diberi ASI usia 0-6 bulan akan menurunkan Angka Kematian Bayi (AKB) sebesar 1,2399 per 1000 kelahiran.

3. Jika variabel dari $t_{1}, t_{2}, t_{4}$ dan $t_{5}$ konstan maka pengaruh dari faktor laju pertumbuhan ekonomi

$\left(t_{3}\right)$ terhadap Angka Kematian Bayi $\left(y_{2}\right)$ adalah sebagai berikut :

$$
\begin{aligned}
\hat{y}_{2}= & -3,0388 t_{3}+61,8769\left(t_{3}-7,3182\right)_{+}-22,2526\left(t_{3}-7,6606\right)_{+} \\
& -69,2209\left(t_{3}-8,6879\right)_{+} \\
& = \begin{cases}-3,0388 t_{3} & ; t_{3}<7,3182 \\
58,8381 t_{3}-452,8275 & ; 7,3182 \leq t_{3}<7,6606 \\
36,5855 t_{3}-282,3592 & ; 7,6606 \leq t_{3}<8,6879 \\
-29,6354 t_{3}+319,0249 & ; t_{3} \geq 8,6879\end{cases}
\end{aligned}
$$

Dari model di atas menjelaskan bahwa jika laju pertumbuhan ekonomi $\left(t_{3}\right)$ kurang dari 7,3182\% maka setiap penambahan $1 \%$ laju pertumbuhan ekonomi, Angka Kematian Bayi (AKB) akan cenderung menurun sebesar 3,0388 per 1000 kelahiran. Jika laju pertumbuhan ekonomi sebesar 7,3182 sampai kurang dari 7,6606\% maka setiap kenaikan 1\% laju pertumbuhan ekonomi akan meningkatkan Angka Kematian 
Bayi (AKB) sebesar 58,8381 per 1000 kelahiran. Jika laju pertumbuhan ekonomi sebesar 7,6606 sampai kurang dari 8,6879 \% maka setiap kenaikan 1\% laju pertumbuhan ekonomi, Angka Kematian Bayi (AKB) cenderung meningkat sebesar 36,5855 per 1000 kelahiran. Jika laju pertumbuhan ekonomi sebesar 8,6879\% atau lebih maka setiap kenaikan 1\% laju pertumbuhan ekonomi akan menurunkan Angka Kematian Bayi (AKB) sebesar 29,6354 per 1000 kelahiran.

4. Jika variabel dari $t_{1}, t_{2}, t_{3}$ dan $t_{5}$ konstan maka pengaruh dari faktor persentase persalinan yang dibantu oleh tenaga medis $\left(t_{4}\right)$ terhadap Angka Kematian Bayi $\left(y_{2}\right)$ adalah sebagai berikut:

$$
\begin{aligned}
\hat{y}_{2}= & 0,5461 t_{4}-18,7592\left(t_{4}-87,1189\right)_{+}+27,8907\left(t_{4}-88,3724\right)_{+} \\
& -13,2474\left(t_{4}-92,1327\right)_{+} \\
= & \begin{array}{ll}
0,5461 t_{4} & ; t_{4}<87,1189 \\
-18,2131 t_{4}-1.634,2808 & ; 87,1189 \leq t_{4}<88,3724 \\
9,6776 t_{4}-830,4872 & ; 88,3724 \leq t_{4}<92,1327 \\
-3,5698 t_{4}-390,0315 & ; t_{4} \geq 92,1327
\end{array}
\end{aligned}
$$

Dari model di atas menjelaskan bahwa jika persentase persalinan yang dibantu oleh tenaga medis $\left(t_{4}\right)$ kurang dari $87,1189 \%$ maka setiap penambahan $1 \%$ persentase persalinan yang dibantu oleh tenaga medis akan meningkatkan Angka Kematian Bayi (AKB) sebesar 0,5461 per 1000 kelahiran. Jika persentase persalinan yang dibantu oleh tenaga medis sebesar 87,1189 sampai kurang dari 88,3724\% maka setiap kenaikan $1 \%$ persentase persalinan yang dibantu oleh tenaga medis akan menurunkan Angka Kematian Bayi (AKB) sebesar 18,2131 per 1000 kelahiran. Jika persentase persalinan yang dibantu oleh tenaga medis sebesar 88,3724 sampai kurang dari 92,1327 \% maka setiap kenaikan $1 \%$ persentase persalinan yang dibantu oleh tenaga medis akan meningkatkan Angka Kematian Bayi (AKB) sebesar 9,6776 per 1000 kelahiran. Jika persentase persalinan yang dibantu oleh tenaga medis sebesar 92,1327\% atau lebih maka setiap kenaikan 1 persentase persalinan yang dibantu oleh tenaga medis akan menurunkan Angka Kematian Bayi (AKB) sebesar 3,5698 per 1000 kelahiran

5. Jika variabel dari $t_{1}, t_{2}, t_{3}$ dan $t_{4}$ konstan maka pengaruh dari faktor persentase penduduk miskin

$t_{5}$ ) terhadap Angka Kematian Bayi $\left(y_{2}\right)$ adalah sebagai berikut :

$$
\begin{aligned}
\hat{y}_{2}= & -1,4888 t_{5}+6,1468\left(t_{5}-21,4189\right)_{+}+2,2983\left(t_{5}-22,4224\right)_{+} \\
& -12,8599\left(t_{5}-25,4327\right)_{+} \\
& = \begin{cases}-1,4888 t_{5} & ; t_{5}<21,4189 \\
4,6580 t_{5}-131,6576 & ; 21,4189 \leq t_{5}<22,4224 \\
6,9563 t_{5}-183,1910 & ; 22,4224 \leq t_{5}<25,4327 \\
-5,9036 t_{5}+143,8708 & ; t_{5} \geq 25,4327\end{cases}
\end{aligned}
$$

Dari model di atas menjelaskan bahwa jika persentase penduduk miskin $\left(t_{5}\right)$ kurang dari 21,4189\% maka setiap penambahan 1\% persentase penduduk miskin akan menurunkan Angka Kematian Bayi (AKB) sebesar 1,4888 per 1000 kelahiran. Jika persentase penduduk miskin sebesar 21,4189 sampai kurang dari 22,4224\% maka setiap kenaikan $1 \%$ persentase penduduk miskin akan meningkatkan Angka Kematian Bayi (AKB) sebesar 4,6580 per 1000 kelahiran. Jika persentase penduduk miskin sebesar 22,4224 sampai kurang dari 25,4327\% maka setiap kenaikan 1 persentase penduduk miskin akan meningkatkan Angka Kematian Bayi (AKB) sebesar 6,9563 per 1000 kelahiran. Jika persentase penduduk miskin sebesar 25,4327\% atau lebih maka setiap kenaikan $1 \%$ persentase penduduk miskin akan menurunkan Angka Kematian Bayi (AKB) sebesar 5,9036 per 1000 kelahiran

\section{KESIMPULAN}

Berdasarkan hasil analisis dan pembahasan yang dilakukan, diperoleh kesimpulan bahwa model regresi nonparametrik spline birespon multivariabel terbaik dengan tiga titik knot. Nilai GCV yang dihasilkan adalah 7,1454 dengan $R^{2}$ sebesar 80,5064. Adapun faktor-faktor yang mempengaruhi adalah: 
Persentase keluarga ber-PHBS, Persentase bayi diberi ASI usia 0-6 bulan, Laju Pertumbuhan Penduduk, Persentase persalinan dibantu oleh tenaga medis (NAKES) dan Persentase penduduk miskin.

\section{DAFTAR PUSTAKA}

[1] Badan Pusat Statistik, Profil Kesehatan Ibu dan Anak, Jakarta Pusat: Badan Pusat Statistik, 2020b

[2] Badan Pusat Statistik. Profil Statistik Kesehatan 2020, Jakarta Pusat: Badan Pusat Statistik. 2020a

[3] Yuliarti, N, Keajaiban ASI: Makanan Terbaik untuk Kesehatan, Kecerdasan dan Kelincahan Si Kecil, Yogyakarta: Andi, 2010

[4] Tarigan, Ingan Ukur. et al, Faktor-Faktor Yang Berhubungan Dengan Pelayanan Bayi di Indonesia: Pendekatan Analisis Multilevel. Jurnal Kesehatan Reproduksi, 8(1), 2017: 103-118. DOI: 10.22435/kespro.v8i1.6879.103-118

[5] Draper, N. Smith, H., Analisis regresi terapan, Jakarta: Gramedia Pustaka Utama, 1992

[6] Wasserman, et. all., Model Linier Terapan Buku II: Analisis Regresi Ganda, Jurusan Statistika FMIPA_IPB, Bogor, 1997

[7] Eubank, R.L.,Spline Smoothing and Nonparametric Regression, New York : Marcel Dekker, 1988

[8] Budiantara, I. N., Spline Dalam Regresi Nonparametrik dan Semiparametrik.Sebuah Permodelan Statistika Masa Kini dan Masa Mendatang.Pidato Pengukuhan Untuk Jabatan Guru Besar Dalam Bidang Ilmu Matematika Statistika dan Probabilitas, Pada Jurusan Statistika, Fakultas MIPA, Institut Teknologi Sepuluh Nopember. Surabaya: ITS Press, 2009

[9] Budiantara, I.N., Model U, GML, CV dan GCV dalam regresi nonparametrik Seminar Nasional Matematika, Surabaya: FMIPA-ITS, Bekerjasama dengan Ikatan Alumni Pasca Sarjana Statistika -ITS, 2005

[10] Similia,T. dan Tikka, J., Input Selection and Shrinkage in Multiresponse Linier Regression : Preprint Submitted to Elsevier, 2007

[11] Wahba, G., Spline Models for Observation Data, SIAM, Philadelphia CBMSNSF Regional Conference Series in Apllied Mathematics, Vol.59, 1990

[12] Oktaviana, Dhina, Regresi Spline Birespon Untuk Memodelkan Kadar Gula Darah Penderita Diabetes Melitus, ITS- paper13021120000202, 2011

[13] Badan Pusat Statistik Jakarta Pusat, Statistik Indonesia Tahun 2017, Jakarta Pusat: Badan Pusat Statistik, 2017

[14] Myttenaere, A. D., Golden, B., Grand, B. L., Rossi, F., Mean Absolute Error for Regression Models. Elsevier, volume 192 halaman 38-48, 2015

[15] Kemenkes RI, Profil Kesehatan Indonesia 2016, Jakarta: Kemenkes RI, 2017 
